\title{
The Dynamic Analytics of Property Law
}

\begin{abstract}
Michael A. Heller ${ }^{*}$
The standard property trilogy of private, commons, and state has become so outdated that it now impedes imagination and innovation at the frontiers of ownership. This essay suggests two approaches creating new ideal types and synthesizing existing ones - that may help update our static property metaphors. Using these dynamic approaches to property analytics, legal theory can move beyond polarizing oppositions that have made jurisprudential debates unsolvable and rendered concrete problems invisible.
\end{abstract}

Metaphors in law are to be narrowly watched, for starting as devices to liberate thought, they end often by enslaving it. ${ }^{\prime}$

Justice Benjamin Cardozo (1926)

\section{INTRODUCTION}

Property theory scholarship works cyclically — reasoning from real-world contests over scarce resources, to analytic tools that translate these struggles into useful conceptual terms, to jurisprudential debates regarding the rightness of resulting allocations, to practical politics that implement one property regime or another, and then back to the on-the-ground struggles which refuse to hold still. What happens if the static categories of property scholarship have gone astray and familiar conceptual terms have failed to keep up with emerging property relations?

Consider the familiar analytic tools of property theory: for example,

* Professor of Law, University of Michigan. Thanks to Hanoch Dagan, Daphna Lewinson-Zamir, Ariel Porat, and the participants at the Cegla Institute Conference on Legal Scholarship. The University of Michigan Law School Cook Endowment provided generous research support.

1 Berkey v. Third Ave. Ry. Co., 244 N.Y. 84, 94, 155 N.E. 58, 61 (1926). 
Blackstone's image of private property as "sole despotic dominion"; 2 Hardin's metaphor of the "tragedy of the commons;" 3 and, more generally, the division of ownership into a trilogy of private, commons, and state forms. ${ }^{4}$ Each of these concepts has a distinguished pedigree and certain present usefulness, but each also imposes a cost when it renders new forms of property invisible. This essay argues that property theory scholarship would benefit from a more dynamic approach to analytics, one better suited to supporting innovations at the frontiers of property.

\section{Should Analytics Be Dynamic?}

Property theorists may be impatient with a focus on analytics and may, indeed, challenge the premise of this essay that analytics can and should be approached more dynamically. If analytics are understood just to mean a workable taxonomy, then little fundamental would be gained by a renewed focus on conceptual work; indeed, analytic property theory would have a marginal role, simply cutting and pruning the well-tended vineyard of property terms. Further work on property concepts would quickly translate into mind-numbing parsing of taxonomic detail in a high Germanic style.

I call this taxonomic view of property analytics the good enough approach. According to this view, we just need a reasonably consistent and intelligible common language of property that is good enough to sustain the more important normative and practical debates that follow. To give an example, note Lawrence Becker's plea for more work on pluralist justifications for property in an article where he bluntly summarizes the current state of theory:

What has been left undone? What has been done to death? ... [An inquiry that has] been done enough (perhaps even overdone) ... is the extensive recapitulation and dissection of the now-standard conceptual analysis of property theory: Hohfeld's analysis of rights, Honoré's

22 William Blackstone, Commentaries on the Laws of England *2 (Univ. of Chicago Press ed. 1979) (1765-1769).

3 Garrett Hardin, The Tragedy of the Commons, 162 Science 1243, 1244-45 (1968).

4 See, e.g., Duncan Kennedy \& Frank I. Michelman, Are Property and Contract Efficient?, 8 Hofstra L. Rev. 711 (1980); Frank I. Michelman, Ethics, Economics and the Law of Property, in 24 NOMOS: Ethics, Economics and the Law 3, 5-6 (J. Roland Pennock \& John W. Chapman eds., 1980); Jeremy Waldron, What is Private Property?, 5 Oxford J. Legal Stud. 313 (1985). 
analysis of ownership, and typologies of justificatory arguments. Tinkering with these matters has become a sort of benign addiction. ${ }^{5}$

In Becker's view, an analytic addiction is at least "benign," rather than pernicious, because "we would lose a great deal of clarity and rigor if [the conceptual apparatus] were ignored." ${ }^{6}$ Still, for Becker, the conceptual front has been adequately covered - it is good enough - and the main work for property theory lies elsewhere.

Similarly, Jeremy Waldron suggests in his jurisprudential work a good enough approach to property analytics. As he puts it, the standard analytic framework "respects both the technician's sensitivity to legal detail and the philosopher's need for a set of well-understood 'ideal types' to serve as the focus of justificatory debate. ${ }^{.7}$ In this view, a dynamic approach to property analytics would be counterproductive because it would scramble the relatively stable, transparent, and neutral-seeming ideal types that allow people to argue productively with each other regarding more substantive issues. ${ }^{8}$

Property theorists also challenge the raison d'être of property analytics from the other end of the spectrum, deploying what I call the never good enough approach. This approach rejects not just the existing analytic framework, but also the possibility of an improved version. For example, Thomas Grey once suggested that private property is, in the end, indefinable in any useful or determinate way and that the categories we use to talk with one another collapse on themselves upon closer examination. ${ }^{9}$ In this view, property analytics, whether static or dynamic, may be understood to be about mystifying real power relations that, in essence, resist categorization. Like the good enough approach, the never good enough criticism does not seem to leave much room for further work on property analytics.

So the challenge from existing property theory is substantial: to thread between, on the one hand, a view that the taxonomies we have already are good enough and normatively empty so further work amounts to, at best, a

Lawrence C. Becker, Too Much Property, 21 Phil. \& Pub. Aff. 196, 197-98 (1992). Id.

7 Jeremy Waldron, Property Law, in A Companion to Philosophy of Law and Legal Theory 3 (Dennis Patterson ed., 1996).

8 See, e.g., Waldron, supra note 4, at 331-32 ("As categories of social, economic, or political science, it is clear that these ideas of a private property system, a collective property system, and a common property system are very much 'ideal typic' categories. It is also clear to quote Weber, 'none of these ideal types ... is usually to be found in historical cases in 'pure' form.') (citing 1 Max Weber, Economy and Society 216 (Guenther Roth \& Claus Wittich eds., 1968)).

9 Thomas C. Grey, The Disintegration of Property, 22 NOMOS 69, 69 (1980). 
benign addiction, and, on the other hand, a position that conceptual work in property is hopelessly indeterminate, obfuscatory, normatively pernicious, and likely a waste of time. Between those views, I propose a more dynamic methodology based on closely observing on-the-ground, emerging property relations; asking whether the existing framework facilitates understanding of and support for these new forms of ownership; and proposing new analytic tools where the present ones fail. Because people are constantly creating new types of property, I suggest that there remains substantial room for analytic innovation in property scholarship, innovation which, in turn, will carry normative punch when it redirects jurisprudential and practical debates to new questions.

\section{The Property Trilogy and Its Discontents}

To illustrate my argument more concretely, the discussion will focus on the preeminent analytic tool of property theory, that is, the well-worn trilogy of ownership forms - private, commons, and state property. While I focus here on the trilogy, any of the other core concepts of property theory, such as the "bundle of rights" image, could equally sustain my argument, a point I discuss briefly in conclusion.

The trilogy of ownership forms has long formed the focal point for normative and practical property debates. ${ }^{10}$ As Frank Michelman states, "We need some reasonably clear conceptions of regimes that are decidedly not [private property], with which [private property] can be compared." process of working from ideal types pervades property theory stretching back past Locke's discussion of the State of Nature and forward to the modern lawand-economics debates. Today, liberals and utilitarians deploy the trilogy in calling for a tilt towards private property; socialists disparage private property and advocate more state control; and communitarians press for expanding the scope of commons property. Theorists push reforms towards one type or the other, but none subjects the trilogy itself to much challenge. The trilogy is so entrenched as to seem almost natural, beyond serious contestation or elaboration. Before we go about constructing new ideal types or synthesizing existing ones, let us briefly recapitulate the trilogy itself. So, what are these ideal types?

10 See, e.g., Jeremy Waldron, The Right to Private Property 44 (1988).

11 Michelman, supra note 4, at 5. 


\section{A. Private Property}

Private property is a complicated idea to pin down precisely; its boundaries fray at the edges. ${ }^{12}$ For property theorists (and for ordinary layfolk ${ }^{13}$ ), the term seems reasonably coherent and capable of simple definition, despite Grey's arguments. ${ }^{14}$ For example, Michelman focuses his definition on rules for initial acquisition and reassignment. He defines sole ownership to mean "the rules must allow that at least some objects of utility or desire can be fully owned by just one person" and freedom of transfer to mean "owners are immune from involuntary deprivation or modification of their ownership rights and empowered to transfer their rights to others at will, in whole or in part." 15 Similarly, Jeremy Waldron defines private property "around the idea that contested resources are to be regarded as separate objects each assigned to the decisional authority of some particular individual (or family or firm)."16

These standard definitions can be multiplied many times over, but all partake of and help keep current William Blackstone's endlessly repeated definition of private property as "that sole and despotic dominion which one man claims and exercises over the external things of the world, in total exclusion of the right of any other individual in the universe. ${ }^{17}$ While the image of sole dominion has never adequately described any real world property ownership, as even Blackstone recognized, ${ }^{18}$ the idea rings through the ages and continues to block clear thinking about private property.

12 See generally Michael A. Heller, The Boundaries of Private Property, 108 Yale L.J. 1163 (1999).

13 See Bruce Ackerman, Private Property and the Constitution 98-100 (1977) (discussing the layperson's view of property as thing-ownership).

14 See text at supra note 9.

15 Michelman, supra note 4, at 4-5. These definitions hearken back to and build another unsteady part of the standard conceptual apparatus of property, crystallized in the Hohfeld-Honoré picture of property as a "bundle of rights." Wesley N. Hohfeld, Fundamental Legal Conceptions as Applied in Judicial Reasoning and Other Legal Essays 96 (Walter W. Cook ed., 1923); A.M. Honoré, Ownership, in Oxford Essays in Jurisprudence 107 (A.G. Guest ed., 1961). See also infra text accompanying notes 30-32 (discussing the bundle of rights metaphor).

16 Waldron, supra note 7, at 6.

17 Blackstone, supra note 2.

18 See Robert W. Gordon, Paradoxical Property, in Early Modern Conceptions of Property 96, 96 (John Brewer \& Susan Staves eds., 1996) (discussing the ever-present thicket of restrictions Blackstone recognized in his day). 


\section{B. Commons Property}

Commons property has been the residual category that theorists usually use when they describe a regime that is not private or state property. Michelman defines a commons property regime as one where "there are never any exclusionary rights. All is privilege. People are legally free to do as they wish, and are able to do, with whatever objects (conceivably including persons) are in the [commons]." ${ }^{19}$ To restate, this definition means that every individual may use any object of property and no individual has the right to stop someone else from using the object.

Although this is not the place to elaborate the point, a useful distinction could be drawn between the utilitarians' image of commons property and the liberals' notion of a State of Nature: the two images share a core definition - everyone has privileges of inclusion and no one has rights of exclusion but have different emphases and contexts. Liberal property theorists usually deploy the State of Nature image to describe a pre-political commons which then evolves towards private property; ${ }^{20}$ while the commons metaphor of modern law-and-economists reflects their goal of explaining the marginal evolution towards private property in specific scarce resources, such as the enclosure of the English commons. ${ }^{21}$ For all these scholars, the transition from commons to private property is the paradigmatic problem that property theory seeks to explain.

19 Michelman, supra note 4, at 5.

20 See Waldron, supra note 4, at 329 ("many philosophers have used the idea of common property to characterize the initial situation of men in relation to resources in the so-called 'State of Nature'"); see, e.g., Blackstone, supra note 2, §§ 2-8; 2 John Locke, Two Treatises of Government at ch. V (Peter Laslett rev. ed. 1963) (3d ed. 1698) (Of Property). Rose uncovers the contradictions that these narratives obscure in moving across the commons/private boundary. Carol M. Róse, Property as Storytelling: Perspectives from Game Theory, Narrative Theory, Feminist Theory, 2 Yale J.L. \& Human. 52 (1990).

21 See, e.g., Terry L. Anderson \& P.J. Hill, The Evolution of Property Rights: A Study of the American West, 12 J.L. \& Econ. 163 (1975) (western land); Harold Demsetz, Toward a Theory of Property Rights, 57 Am. Econ. Rev. 347, 354 (1967) (furtrappers); H. Scott Gordon, The Economic Theory of a Common-Property Resource: The Fishery, 62 J. Pol. Econ. 124 (1954); D. Bruce Johnsen, The Formation and Protection of Property Rights Among the Southern Kwakiutl Indians, 15 J. Legal Stud. 41 (1986) (potlaching); Arthur F. McEvoy, The Fisherman's Problem (1986) (fisheries); John Umbeck, A Theory of Contract Choice and the California Gold Rush, 20 J.L. \& Econ. 421 (1977) (gold fields). 


\section{State Property}

State property, also sometimes called collective property, can be defined as a property regime in which

[i]n principle, material resources are answerable to the needs and purposes of society as a whole, whatever they are and however they are determined, rather than to the needs and purposes of particular individuals considered on their own. No individual has such an intimate association with any object that he can make decisions about its use without reference to the interests of the collective. ${ }^{22}$

As Jeremy Waldron notes, a state property regime is similar to commons property in that no individual stands in a specially privileged position with regard to any resource, but is distinguished from commons property in that the state has a special status or distinct interest - that of owner of all resources, able to include or exclude all individuals according to the rules of that particular state. ${ }^{23}$ In other words, the collective, represented usually by the state, holds all rights of exclusion and is the sole locus of decision-making regarding use of resources. So, a subsidiary set of questions need to be answered to specify a state property regime fully, including what is the "collective interest" and what procedures will be used to apply that conception to a particular case.

Today, for most property theorists, state property has become a less and less important category, particularly since the decline of socialist states and rise of the worldwide movement towards privatization. ${ }^{24}$ For liberal, communitarian, and utilitarian theorists alike, the trilogy may effectively reduce down to a dichotomy - private and commons - so that all theoretical work takes place in the interplay of these two regimes. For example, Michelman says that a commons can be seen as "a scheme of universally distributed, all-encompassing privilege ... that is opposite to

22 Waldron, supra note 4, at 328-29, 329 n.45; see also C.B. MacPherson, Property: Mainstream and Critical Positions 5-6 (1978) (substantially the same definition of state property).

23 Waldron, supra note 4, at 329.

24 Property theorists always recognize that any actual regime will contain all elements of the trilogy we have identified, but they maintain the distinctions among the types. See, e.g., Robert C. Ellickson, Property in Land, 102 Yale L.J. 1305, 1381, 1381 n.342 (1993) (noting that large U.S. cities devote about $25 \%$ of developed land to highways and streets and $10 \%$ more to public parks); see also id. at 1397 n.413 (commenting that both law-and-economics and critical legal scholars have come to share the view that land regimes inevitably will (and implicitly should) mix private and public elements). 
[private property]."25 Similarly, the economist Yoram Barzel notes that the standard economic analysis of property has "tended to classify ownership status into the categories all and none, the latter being termed 'common property' - property that has no restrictions put on its use." 26

\section{Two Approaches to the Property Trilogy}

The ideal-typic trilogy straight-jackets analysis. For example, when people share access to resources in a commons and then proceed to waste the resources through overuse, theorists see an instance of Hardin's metaphor of the "tragedy of the commons" - another core concept of property law. By looking to the trilogy, the liberals and utilitarians see conservation solutions that require either privatization or state control, while communitarians search for those limited circumstances in which close-knit groups can avoid tragedy. The tragedy of the commons metaphor may be deployed simultaneously to provide moral justification for private property regimes, to promote state regulation, and to disparage the practical possibilities for cooperative use of resources.

As we shall see, there are at least two productive ways to move beyond the existing trilogy. First, there is what I call a constructive approach, which responds to real world property developments by offering a new ideal type. For example, I have developed "anticommons" property as a fourth ideal type, a type that leads to a new set of normative questions and practical possibilities for property. One consequence of adding this ideal type of property to the analytic toolkit is to give voice to previously inchoate worries about the progressive march of privatization, to explain why too much private property can be as costly as too little. Second, the existing trilogy can be challenged using what I call an integrative approach that brings together elements of the existing ideal types and reveals characteristics of them that are quite distinct. Consider here emerging property regimes that Carol Rose identifies as "limited commons property" and property relations that Hanoch Dagan and I call the "liberal commons" - emerging real-world property types that constitute what we believe may be the future

25 Michelman, supra note 4, at 5, 9 ("... a scheme of universally distributed, allencompassing privilege is, precisely a commons, a type of regime ([state of nature]) that is opposite to [private property] ...") (italics omitted); see also Waldron, supra note 4, at 329.

26 Yoram Barzel, Economic Analysis of Property Rights 71 (1989). 
of property. ${ }^{27}$ The standard trilogy misses what is most distinctive, perplexing, and important about these regimes, which is the "property governance" rules people are creating for themselves in new ownership forms, forms not implied either by the image of sole despotic dominion or of a commons. Let us consider constructive and integrative approaches to property analytics in turn.

\section{A. The Constructive Approach}

While there are many ways to go outside the usual trilogy, this section will set out just the anticommons ideal type.$^{28}$ Consider new areas for property law, such as the problem of spurring private investment in biomedical research or creating well-functioning markets in post-socialist economies. In both cases, recent reforms aimed to create well-functioning private property regimes, but instead had surprising results, in part by threatening to strand resources in wasteful uses, to deter rather than promote innovation and production. By drawing the wrong property boundaries around resources, by fragmenting ownership too much, it turns out that privatization can destroy resource productivity in enduring ways. To capture these unexpected results from excessive privatization, I have proposed the idea of anticommons property, an image that goes beyond the old trilogy and crystallizes emerging real-world property relations that had previously remained invisible.

Anticommons property can be best understood as the mirror image of commons property. A resource is prone to overuse in a tragedy of the commons when too many owners each have a privilege to use a given resource, and no one has a right to exclude others. By contrast, a resource is prone to underuse in a tragedy of the anticommons when multiple owners each have a right to exclude others from a scarce resource and no one has an effective privilege of use. In theory, in a world of costless transactions, people could always avoid common or anticommons tragedy by trading their rights. In practice, however, avoiding tragedy requires overcoming transaction costs, strategic behaviors, and cognitive biases of participants, with success more likely within close-knit communities than among hostile

27 Hanoch Dagan \& Michael A. Heller, The Liberal Commons, 110 Yale L.J. 549 (2001); Carol M. Rose, The Several Futures of Property: Of Cyberspace and Folk Tales, Emissions Trades and Ecosystems, 83 Minn. L. Rev. 129 (1998).

28 The material in this section that defines anticommons property is drawn substantially from Michael A. Heller, The Tragedy of the Anticommons: Property in the Transition from Marx to Markets, 111 Harv. L. Rev. 621 (1998), while the biomedical research example comes from Michael A. Heller \& Rebecca S. Eisenberg, Can Patents Deter Innovation? The Anticommons in Biomedical Research, 280 Science 698 (1998). 
strangers. Once an anticommons emerges, collecting rights into usable private property is often brutal and slow.

My definition of anticommons property is constructed in such a way as to render it useful for describing emerging real-world property regimes. For example, to have an anticommons I do not require that everyone hold rights of exclusion, but only that a limited group of owners be able to block one another. Waste through nonuse can occur even when a few actors have rights of exclusion in a resource that each wants to use. Also, my definition does not require that nonuse be optimal. There are many situations in which nonuse results from excessive fragmentation, but is not socially desirable. For most resources that people care about, some level of use is preferable to nonuse, and an anticommons regime is a threat to, rather than the epitome of, productive use. Finally, an anticommons may be created even when multiple rights of exclusion are not formally granted through the legal system.

Legal and economic scholars have mostly overlooked this tragedy, in part because it did not fit within the familiar property trilogy, but waste through underuse can appear whenever governments create new property rights. I developed the idea initially from closely observing privatization in post-socialist economies. One promise of transition to markets was that new entrepreneurs would fill stores that socialist rule had left bare. Yet after several years of reform, many privatized storefronts remained empty, while flimsy metal kiosks, stocked full of goods, mushroomed up on the streets. Why did the new merchants not come in from the cold? One reason was that transition governments often failed to endow any individual with a bundle of rights that represents full ownership. Instead, fragmented rights were distributed to various socialist-era stakeholders, including private or quasi-private enterprises, workers' collectives, privatization agencies, and local, regional, and federal governments. No one could set up shop without first collecting rights from each of the other owners.

Privatization of upstream biomedical research in the United States may create anticommons property that is less visible than empty storefronts, but even more economically and socially costly. In this setting, privatization takes the form of intellectual property claims to the sorts of research results that, in an earlier era, would have been made freely available in the public domain. Today, upstream research in the biomedical sciences is increasingly likely to be "private" in one or more senses of the term - supported by private funds, carried out in a private institution, or privately appropriated through patents, trade secrecy, or agreements that restrict the use of materials and data. An anticommons in biomedical research may be more likely to endure than in other areas of intellectual property because of high transaction costs of bargaining, heterogeneous interests among owners, and cognitive 
biases of researchers. But there is little public outcry to fix a biomedical anticommons because the price people pay is in the form of lifesaving drugs that are not discovered. Too many people hold intellectual property rights that let them block each other from carrying out the necessary research.

Like the transition to free markets in post-socialist economies, privatization of biomedical research offers both promises and risks. It promises to spur private investment, but risks creating a tragedy of the anticommons through a proliferation of fragmented and overlapping property rights. Constructing the anticommons ideal type helps to show why privatization must be more carefully deployed if it is to serve the public goals of biomedical research and post-socialist transition. Otherwise, in the biomedical context more upstream rights may lead paradoxically to fewer useful products for improving human health, and in post-socialism, excessive privatization can have the unintended effect of turning people against the benefits of market reforms. Adding the idea of anticommons property to our analytic toolkit - going beyond the familiar trilogy - helps to reveal precisely how privatization can cause an unexpected, new form of resource tragedy as it solves an old, familiar dilemma.

\section{B. The Integrative Approach}

By contrast, what I call the integrative approach draws new life from existing analytic categories. Consider how property theory should treat the striking new forms of cooperation that are emerging within common interest residential communities. The core theoretical issues in a condominium are not those associated with the Blackstonian image of private property in which owners with sole despotic dominion struggle against each other problems traditionally covered by laws of nuisance and land use regulation. Nor is a condominium best characterized by the waste associated with an open access commons, a problem often resolved by state regulation. Despite not fitting within the existing analytic boxes, common interest communities are becoming one of the predominant forms of real property organization, as the world becomes more crowded.

My current work with Hanoch Dagan illustrates the integrative approach to property analytics. ${ }^{29} \mathrm{We}$ look at the complex forms of internal self-governance that make cooperation work in new property regimes and then abstract from those practical solutions to re-conceptualize the private and commons ideal types of ownership. Integrating those two forms suggests a new analytic tool, what we call "the liberal commons." In our definition, a liberal commons is a

29 This section draws substantially from Dagan \& Heller, supra note 27. 
legal regime that enables a limited group of owners to capture the economic and social benefits from cooperative use of a scarce resource, while also ensuring autonomy to individual members who each retain a secure right to exit.

The liberal commons challenges entrenched property theory built on oppositions inherent in the existing trilogy. According to these entrenched views, the liberal commons is an oxymoron in theory, impossible in practice, and therefore unworthy of support by law. "Communitarians," who celebrate successful commons property regimes, openly promote their illiberal character. They emphasize that restrictions on exit are essential in a flourishing community, for only by locking people together can small, close-knit groups develop the informal norms key to conserving commons resources. "Privatizers" counter that breaking up commons property augurs better for efficiency and autonomy. Most economists join this camp because they worry that rational owners will over-consume commons resources, while most liberals join in because they object to locking people together. "Regulators" call for state command and control where communitarian or privatization approaches cannot apply. For all, the opposition of commons and private property proves an ideal foil, a shared counterpoint for otherwise competing advocates of community, efficiency, autonomy, and state authority.

Our approach rejects the oppositions between private and commons property. More precisely, by integrating these types in theory and showing how these types can work together in practice, we dissolve the "tragedy of the commons" conundrum. The tragedy metaphor has long been understood to refer to the problem of tragic outcomes. In recent years, communitarians answered the outcome debate by showing that a commons can succeed, but only in an illiberal environment. Liberals justifiably countered that illiberal successes are still tragic and pushed for privatization. Seen through our prism, the debate between the communitarians and the liberals relies too heavily on false oppositions between commons and private property. Rightly considered, their debate should be reframed in terms of the question of tragic choice: are we doomed to choose between our liberal commitments and the economic and social benefits available in a commons? Constructing a liberal commons is, indeed, a challenge, but it is not inherently contradictory or practically unattainable - though the familiar trilogy obscures the meaning of already-existing integrative solutions.

In our view, marital property, trusts, condominiums, partnerships, and corporations all belong under a single analytic umbrella: they can be forms of liberal commons property. Each is a legal invention that encourages 
people voluntarily to come together and create limited-access and limitedpurpose communities dedicated to shared management of a scarce resource. Each offers internal self-governance mechanisms to facilitate cooperation and the peaceable joint creation of wealth, while simultaneously limiting minority oppression and allowing exit. For more and more resources, the old-fashioned image of sole private property has become impracticable, leading people to create pervasive, though unremarked, variations on our theme of a liberal commons.

By introducing the liberal commons as an analytic tool, we make the already-existing liberal commons regimes more visible and more tractable for normative and practical property theory work. For example, the idea of a liberal commons helps draw attention to a puzzle: why is there such a sharp contrast between existing liberal commons regimes and the unified hostility of legal theory and default property law to cooperation? Our analytic tool can be deployed wherever people want to work together but are prevented from doing so by background property rules premised on the old-fashioned Blackstonian image of private property and the unreflective hostility to cooperation built into the tragedy of the commons image. By showing how a liberal commons can integrate the benefits of private and commons forms, this dynamic approach to property analytics advances normative and practical property projects.

\section{Deploying the Two Methods}

A dynamic approach to property analytics looks to the chaos of real world relations and identifies some puzzle that is not well-captured by the existing framework, something new, something striking - a conundrum hidden or mis-described by the existing trilogy. While each puzzle requires its own analytic solutions, both the constructive and integrative methods share the key feature of starting from a concrete observation, abstracting from that observation so that its normative and practical implications crystallize in a new analytic tool, and then using that tool to make innovative solutions more easily imaginable.

The two approaches also differ according to the limitations imposed by existing analytic tools. The problem of excessive fragmentation of property appears in what had been terra incognita, on the other side of the spectrum of ownership from commons to private property. So, constructing an anticommons type has the effect of putting private property in the middle of a continuum, and the possibility of "too much" property then becomes more visible. By contrast, the integrative method works better when the problem is to draw out new implications from existing ideal types. For example, Dagan and I noticed that the images of private and commons 
property had always been interpreted in opposition, but that real-world property relations were melding the two forms together to create something quite distinct. By identifying what we call a liberal commons, existing private and commons property types can be re-deployed to support the gains possible from emerging forms of cooperation in managing scarce resources.

When should a constructive approach be used? When an integrative one? So far, I cannot discern any hard rules to govern the choice of analytics. Each method is always available; the goal and measure of a dynamic approach to property analytics is simplicity and persuasion.

\section{SOME Fur'THER STEPS: BEyOND THE "BundLE OF RightS"}

Just as the trilogy of property forms can be usefully expanded and revised, so can the other tools of property analytics. The idea of ownership as a "bundle of rights" is perhaps the property concept most in need today of ambitious constructive and integrative work. The bundle metaphor is pervasive in property-speak. Yet while it structures large segments of theoretical and practical debate, it poorly describes emerging property innovations and problems.

According to the stylized history taught to generations of law students and applied by judges every day, ${ }^{30}$ people understood property as a physical thing or a legal thing until this century, when lawyers recast it as an abstract bundle of legal relations. The standard Hohfeld-Honoré story is a remarkably thin account of ownership, but still rather universal. Neither the old propertyas-thing metaphor nor the current property-as-bundle metaphor conveys well the nuanced way law structures control over scarce resources. In particular, the idea of property-as-thing misses the complex internal relations among owners of a thing - what Dagan and I call the liberal commons - while the modern bundle metaphor suggests more fluidity than appears in existing property relations. This section just briefly introduces the shift from thing to bundle and suggests why more analytic work may be useful in moving to the next, better-organizing metaphor.

Under the old metaphor, property involves the physical ownership of discrete, individually-owned things, an image symbolized by the medieval ceremony of livery of seisin, which gathered people in a field to exchange ownership by handing over a clod of dirt. This thing-ownership metaphor is conventionally summarized in Blackstone's talismanic quotation that private

30 The material in this section is drawn from Heller, supra note 12. 
property is "that sole and despotic dominion which one man claims over the external things of the world, in total exclusion of the right of any other individual in the universe. ${ }^{31}$ Similarly, the idea of private property as a "legal thing," which arises in part because ownership has no intrinsic form, has a lineage as ancient as the image of property as a "physical thing." Fees, life estates, easements, and leases all represent complex legal things distinct from physical things. Although superseded in property theory, the thing-ownership metaphor continues today as a theme in popular understanding. It is easy to think of a house or a field or a farm as a thing because resources defined on this scale can be put to productive use. The problem with the thing-ownership metaphor is that it does not help identify boundaries of complex governance arrangements and modern intangible property.

The metaphoric shift from thing-ownership to bundle of relations can be traced to the late $1800 \mathrm{~s} \mathrm{~s}^{32}$ Though its modern version is usually attributed to Hohfeld, he never mentioned a "bundle of rights." Nevertheless, he developed the now standard idea that property comprises a complex aggregate of social and legal relationships made up of rights, privileges, duties, and immunities. This vision contrasts with "the simple and nonsocial relation between a person and a thing that Blackstone's description suggested." ${ }^{33}$ The Hohfeldian view moved quickly from legal theory into the 1936 Restatement of Property and from there into mainstream scholarship and judicial decision-making. For example, the American Law of Property defines private property to be "an aggregate of legal relations which has economic or sale value if transfer be allowed." 34

Despite the pervasiveness of this image, I have elsewhere shown how the open-ended bundle of property rights image can have pernicious consequences. ${ }^{35}$ While the modern bundle of legal relations metaphor captures the possibility of complex fragmentation, it gives a weak sense of the

31 Blackstone, supra note 2.

32 The earliest use of the term bundle of rights appears to be from John Lewis, in his 1888 treatise The Law of Eminent Domain. See J.E. Penner, The "Bundle of Rights" Picture of Property, 43 UCLA L. Rev. 713 n.8 (1996) (tracing the metaphor); Kenneth J. Vandevelde, The New Property of the Nineteenth Century: The Development of the Modern Conception of Property, 29 Buff. L. Rev. 325 (1980) (same).

33 Gregory S. Alexander, Commodity \& Propriety: Competing Visions of Property in American Legal Thought, 1776-1970, at 319 (1997).

346 American Law of Property $\$ 26.1$ n.15 (A. James Carter ed., 1952 \& 1977 Supp.); see also American Law Institute, Restatement of Property 2-6 (1936) (adopting a Hohfeldian definition of property).

35 Heller, supra note 12 , at $\cdot 1202-21$ (criticizing Supreme Court takings jurisprudence). 
"thingness" still inherent in private property. So long as property theorists continue to rely on the modern bundle of legal relations metaphor, they need some analytical tool to distinguish things from fragments, bundles from rights, and private from non-private property. Lacking such a perspective has practical consequences. For example, as I have shown, the U.S. Supreme Court has adopted uncritically the bundle of rights view of property and used it inadvertently to collapse the idea of private property as a distinct economic and Constitutional category.

As the bundle of rights waxes in judicial decision-making, it is waning in property theory. Carol Rose has proposed moving away from land to water as a core organizing image for property; ${ }^{36}$ J.E. Penner has written caustically that "I believe in giving dead concepts [such as the bundle of rights metaphor] a decent burial" ${ }^{\prime 37}$; and in conversation, property scholars Brian Simpson and Gregory Alexander concur that the time has come for a better core metaphor. A constructive analytic approach could perhaps recharacterize existing metaphors as Newtonian holdovers and propose moving to something more up-to-date, such as a quantum or string-theory metaphor. This is whimsical: to be persuasive, such a constructed term must resonate with existing property debates while it better describes new possibilities. Alternatively, an integrative analytic approach might look to re-describing the familiar opposition of property as thing and property as bundle. Perhaps we can follow Rose's lead and think through the implications of switching from land to water. Water always conjures complex relational rights. Whether following a constructive or integrative approach, the next step for property analytics is to shift the debate towards new perspectives on familiar puzzles.

\section{ConClusion}

Ideal typical understandings of property frame the normative and practical debates that matter. What happens if the core of what is property evolves, mutates, refuses to hold still? For example, what if the existing trilogy of property forms - private, commons, and state - hides tragedy and impedes innovation at the frontiers of property? Then a more dynamic approach to the analytics of property carries a normative punch. Beyond the standard trilogy lies new and useful analytic tools, not just anticommons property

36 Carol M. Rose, Property as the Keystone Right?, 71 Notre Dame L. Rev. 329, 351 (1996) (comparing land and water as metaphors for property).

37 Penner, supra note 32 , at 819. 
and the liberal commons, but also as yet unimagined property types that will respond to new real-world property puzzles. A dynamic approach to property analytics can deploy constructive and integrative approaches to update the other hoary metaphors of property law, such as the bundle of rights image.

None of the basic terms for property are stable. This is not to say that they are meaningless or disintegrating, but that property scholarship can gain from pushing these categories to reflect better changing on-theground relations. By making property analytics more dynamic, we can move beyond polarizing oppositions that render practical problems invisible and jurisprudential debates unresolvable. 
Heinonline -- 2 Theoretical Inq. L. 962001 